Available online at website : http://e-journal.adpgmiindonesia.com/index.php/jmie JMIE: Journal of Madrasah Ibtidaiyah Education, 3(2), 2019, 179-188

\title{
EVALUATING THE PROFESSIONAL DUTIES OF CLASSROOM TEACHERS IN PRIMARY SCHOOLS
}

\author{
Asep Ediana Latip \\ UIN Syarif Hidayatullah Jakarta \\ Email: asep.ediana@uinjkt.ac.id
}

Naskah diterima : 21 Agustus 2019, direvisi : 23 September 2019, disetujui : 26 September 2019

\begin{abstract}
The purpose of this study was to evaluate the learning of certified and un-certified class teachers in primary schools. The research method used is evaluation. The research sample is classroom teachers found in Jakarta, Bogor, Depok, Tangerang, and Bekasi. Data collection techniques used are performance test and document analysis. The sampling technique used was purposive sampling. Data analysis was performed quantitatively and qualitatively descriptively. The results of the study explained that $80 \%$ of elementary school classroom teachers can professionally carry out their duties very well. In planning learning activities certified teacher classes have a good quality guarantee compared to uncertified classroom teachers, meanwhile in learning activities certified class teachers and those who have not been professionally certified are very good at being able to carry out learning activities in primary schools.
\end{abstract}

Keywords: Learning Evaluation, Classroom Teachers, Primary School

Pengutipan: . Asep Ediana Latip. (2019). Evaluating the Professional Duties of Classroom Teachers in Primary Schools. JMIE: Journal of Madrasah Ibtidaiyah Education,3(2), 2019, 179-188. jmie.v3i2.133.

Permalink/DOI: http://dx.doi.org/10.32934/jmie.v3i2.133 


\section{INTRODUCTION}

In Elementary Schools, there are educators who have the role of class teachers. Class teachers are educators who carry out their professional duties at the elementary / elementary school level with thematic learning processes that include Natural Sciences, Indonesian Language, Social Sciences, Citizenship Education, and mathematics and even Cultural Arts and Crafts, Physical Education, Sports and health and Religious Education and Character. The role of the classroom teacher is an effective role for the level of basic education because it represents the psychology of students of MI / elementary school age children who need an effective teacher personality (Gao and Liu, 2013).

It is important as a classroom teacher to be able to effectively carry out tasks with professionals both in developing learning plans and in carrying out learning at the level of basic education (Colker, 2008). This is also explained by Smith \& Ragan and likewise Poulsen, Aura (2008) that a learning plan is developed in the context of a goal directed process; the process of directing the achievement of learning objectives, design requires social interaction; meet the development of social interaction, and designing involves problem soving; and designing acquisition of problem solving in learning.

There are several benefits in designing learning planning that Smith \& Ragan explains, namely: Encouraging advocacy of the learner, Support effective, efficient, and appealing instruction, Support coordination, among designers, developers, and those who will implement the instruction, Facilitates diffusion / dissemination / adoption, Support development for alternate delivery systems, Facilitates congruence among objectives, activities, and assessments, Providers a systematic framework for dealing with learning problems, Requerse identification of outcomes, and Requerse leed time.

Based on some of the benefits above, it can be ascertained that if the class teacher cannot develop a learning planning design will certainly lose the benefits above, and certainly lose the significance of learning planning, among them is that the effectiveness, efficiency and attractiveness in the learning process will not be realized optimally (Crooks, 1998). As the results of research conducted by Bambang S. Sulasmono (2015) on the Evaluation of Teaching Performance of Certified Class V Teachers in the Fostered Area 2 of Parakan District, explained that $88.89 \%$ of certified teachers in the Fostered Area 2 of Parakan District had good teaching performance, and $11.11 \%$ very good at the planning, implementation, and evaluation stages of learning. However, there are several aspects of teaching performance that need to be improved because it is still in the sufficient category, including: (1) planning the selection of media and learning resources, (2) applying ICT in learning, (3) applying contextual learning, (3) 
choosing learning methods, and (4) lattice questions for evaluation of learning. Arif Purnomo (2007) in his research entitled Teacher's Ability in Designing Multiple Choice Tests in Social Sciences Subjects for Final School Examination (UAS) concluded that based on the analysis of the IPS test set tested at UAS in three Primary Schools in Gajah Mungkur District, Semarang, it turned out most of it can not be used because it does not meet the requirements of validity, reliability, the level of difficulty of the questions and the different power of the questions.

In this study the evaluation of classroom teacher learning is based on the theory of Smith \& Ragan (tt) which includes planning and implementing learning activities. In planning learning activities include aspects of setting learning objectives, developing learning strategies, and developing learning evaluations. In setting learning objectives (instructional objectives), class teachers are advised to be able to analyze learning contexts (learning environments), learners (learners), and learning tasks (learners' learning tasks). In an effort to set learning objectives, as a designer, a teacher can answer analytical questions such as those developed by Smith and Ragan between them: how long does it take in learning ?, how will students feel in implementing learning?, what is the background knowledge of the participants students? what knowledge and skills do students want to have?, and how can learning objectives be assessed? In developing learning strategies it is recommended that class teachers analyze the management of learning strategies and the organizing of learning strategies. Efforts to develop these learning strategies can be used to analyze the questions used by Smith and Ragan among them: what content will learners learn? how many students will be involved in learning ?, will the material be presented, or is it achieved by students in learning activities ?, what learning activities can involve students ?, what activities are ongoing in the learning process, is it discovery, or exspository?, What media are appropriate in learning; should students see firsthand, or sufficient students by reading learning resources?, and whether students can learn individually, in groups or with pairs and whether the group developed is a small group or a large group ?. In developing learning evaluations, class teachers should analyze the learning outcomes that have been set as learning objectives. Efforts to optimize the learning evaluation process can be followed by suggestions submitted by Smith and Ragan including: is the learning material appropriate? Is the assessment done individually or in groups? What are the questions asked to students? What is the form of learning improvement after learning outcomes are obtained? learners?.

Likewise explained in Permendikbud No. 22 of 2016 concerning the standard process explained that learning planning can be prepared by meeting the principle of individual differences of students, active participation of students, centered on students, development of 
reading and writing culture, giving feedback and follow-up, emphasis on the interrelation and integration of competencies, and accommodating thematic learning.

In learning based on learning principles that are oriented to the activities of students mentioned in Permendikbud No. 22 of 2016 concerning Process Standards, among them students are told to learn students and from the teacher as the only source of learning becomes learning based on various learning resources; from a textual approach to the process as a reinforcement of the use of scientific approaches. The theory underlying learning implementation is the scientific approach model and 5E Instructional Model Bybee (2009) (Engineering, Exploration, Explanation, elaboration, and evalution) elaborated with Permendikbud No 22 of 2016 on standard processes divided into preliminary, core and closing activities.

The ideal theory of learning may not also be implemented in praxis in schools, various research results he explained among the phenomena of class teachers who have not perfectly carried out their professional assignments, as well as certified teachers may not necessarily be able to demonstrate the quality of professional learning very well in carrying out their tasks especially in planning and implementation of learning and assessment of student learning outcomes. Therefore, in the context of this study an evaluation of classroom teachers will be carried out in the planning and implementation of learning in the regions of Jakarta, Bogor, Depok, Bekasi, and Bogor.

Based on the above background, several research problems can be formulated, namely How are certified and uncertified class teachers in planning learning in primary school ?, How are certified and uncertified class teachers in implementing learning in primary school?

\section{RESEARCH METHODS}

This research method is an evaluation research that is research conducted to measure, evaluate and evaluate the planning and implementation of classroom teacher learning in primary school. The research sample consisted of 84 primary school class teachers in Jakarta, Bogor, Depok, Tangerang and Bekasi. The evaluation instruments as data collectors for this study were performance tests and portfolios with a Likkert rating scale.

The data obtained were analyzed quantitatively and qualitatively. Data obtained from the results of performance tests and portfolios with a score based on the Likkert scale are converted to a score of 1-100 scale then converted to a value so that the rubric is if obtained a score of 61-70 qualitatively described with sufficient value, if a score of 71-80 is obtained, then qualitatively can be described qualitatively with good scores, and if obtained a score of 81-100 
can be described qualitatively with a very good value, then the assessment results are interpreted with follow-up in the form of corrected, improved and continued. Examination of the validity of the data in this study follows the inspection steps developed by Robert, K. Yin (2011) consisting of intensive long-term field involvement, and the process of examining the reliability of research data covering credibility, dependability, transferability and confirmability (Sugiyono, 2012).

\section{RESEARCH RESULTS AND DISCUSSION}

Evidence of professionalism in classroom teachers is proven by obtaining teacher certificates. In obtaining a certificate, teachers are required to participate in coaching with various activities including evaluation of the teacher portfolio, qualification improvement programs, training programs and teacher training and teacher professional programs and subsequently conducted teacher competency tests. MI / SD class teachers in Jakarta, Bogor, Depok, Tangerang and Bekasi are already certified and some are not certified. Class teachers who have met the requirements of teaching experience and meet the qualification criteria that are linear can take part in the teacher certification program. The average teacher who has not been certified is due to the experience of the teacher's tenure and does not meet other requirements.

Certified classroom teacher means that it has been tested competently. National and standardized competencies are professional, personality, social and pedagogical competencies. Even so that teachers who have not been certified does not mean they do not have the competence in carrying out their duties. However, authentic data is needed to illustrate this point. Therefore, the results of this study are expected to illustrate the professionalism of class teachers in carrying out professional tasks in carrying out in learning activities in primary schools especially in the areas of Jakarta, Bogor, Depok, Tangerang and Bekasi.

Based on the results of the study illustrated that $80 \%$ of elementary school class teachers in Jakarta, Bogor, Depok, Tangerang and Bekasi can carry out their duties professionally, while $20 \%$ are still not professionally performing their duties as illustrated in the pie chart as follows: 


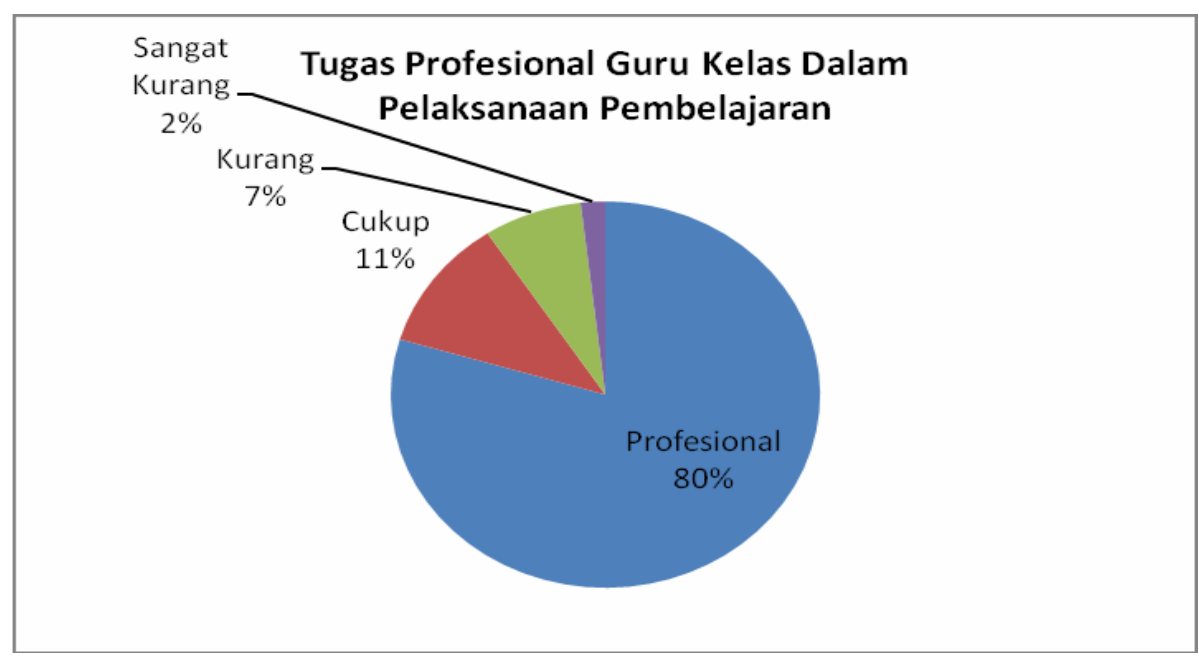

Diagram 1

Among the professional tasks of elementary school classroom teachers are the preparation of learning plans and the implementation of learning activities. The following are the results of an evaluation of the professionalism of classroom teachers in designing planning and implementing learning in primary schools.

\section{a. Classroom Teacher Evaluation in Planning Learning}

In planning learning explained by Smith \& Ragan which includes activities setting learning objectives, developing learning strategies, and developing learning evaluations. Based on the results of a portfolio analysis in the form of a lesson plan (RPP) designed by elementary school class teachers in Jakarta, Bogor, Depok, Tangerang, and Bekasi, it is illustrated as follows, namely: 


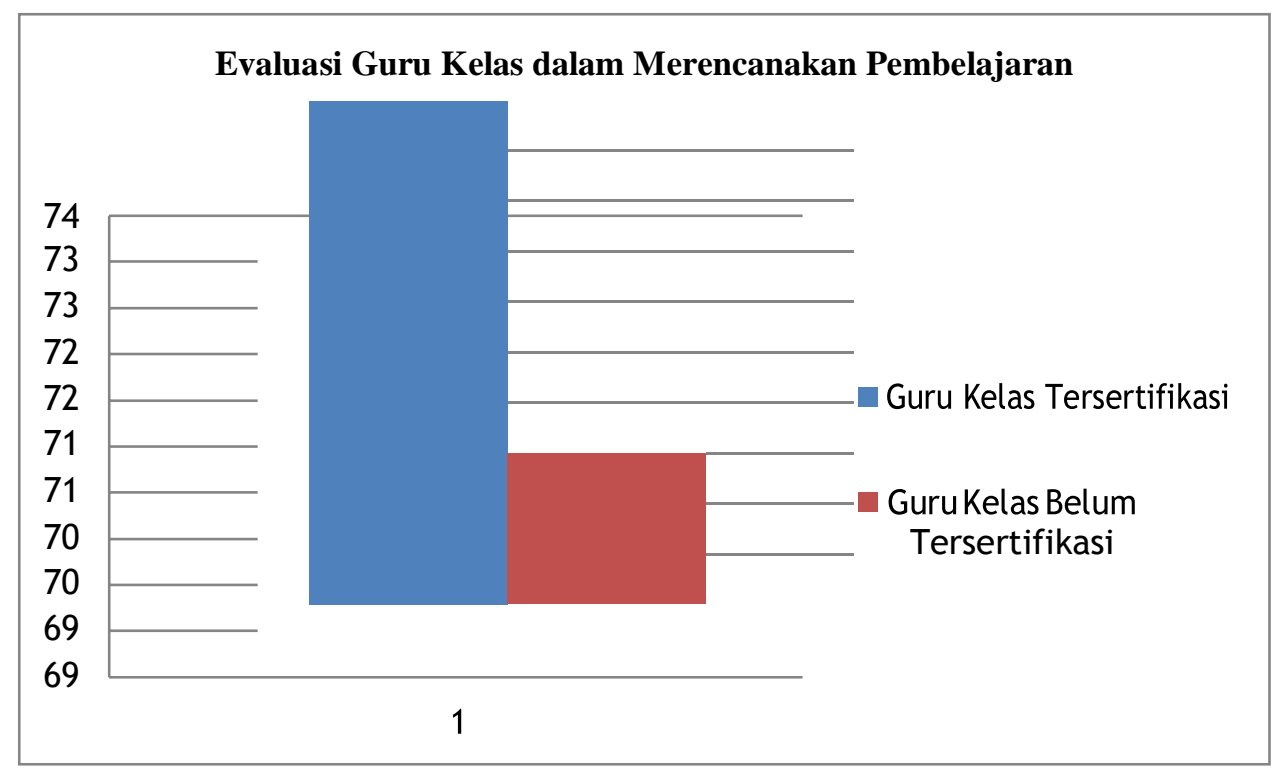

\section{Diagram 2. Evaluasi Guru Kelas dalam Merancang Pembelajaran}

Based on the data above, it is known that certified class teachers get an average score of 73, while uncertified class teachers get an average score of 70 . Based on these scores when converted qualitatively it can be stated that certified class teachers get good grades and class teachers have not certified to obtain sufficient value in planning learning. This means that certified classroom teachers need to make efforts to improve quality in the preparation of learning plans so that they can pay attention to the principles in the preparation of learning plans. Moreover, uncertified class teachers are urgently needed to continue to strive to get better quality in preparing learning plans and can be immediately certified.

\section{b. Evaluation of Class Teachers in Implementing Learning Activities}

Class teachers in carrying out learning based on Permendikbud No. 22 of 2016 on standard processes are implementing pre-learning activities such as preparing spaces, and learning tools and media. Carry out preliminary activities such as opening learning, doing apperception, and conveying competency indicators and motivating students to be actively involved in the learning process. Carry out core learning activities consisting of mastery of subject matter, use of learning strategies, use of learning resources or learning media, learning that triggers and maintains student involvement, assessment of learning processes and 
outcomes, use of language in learning and closing activities consisting of assessment activities, reflection and action plan both remedial and enrichment. Based on the results of the study obtained data as illustrated in the following graphic:

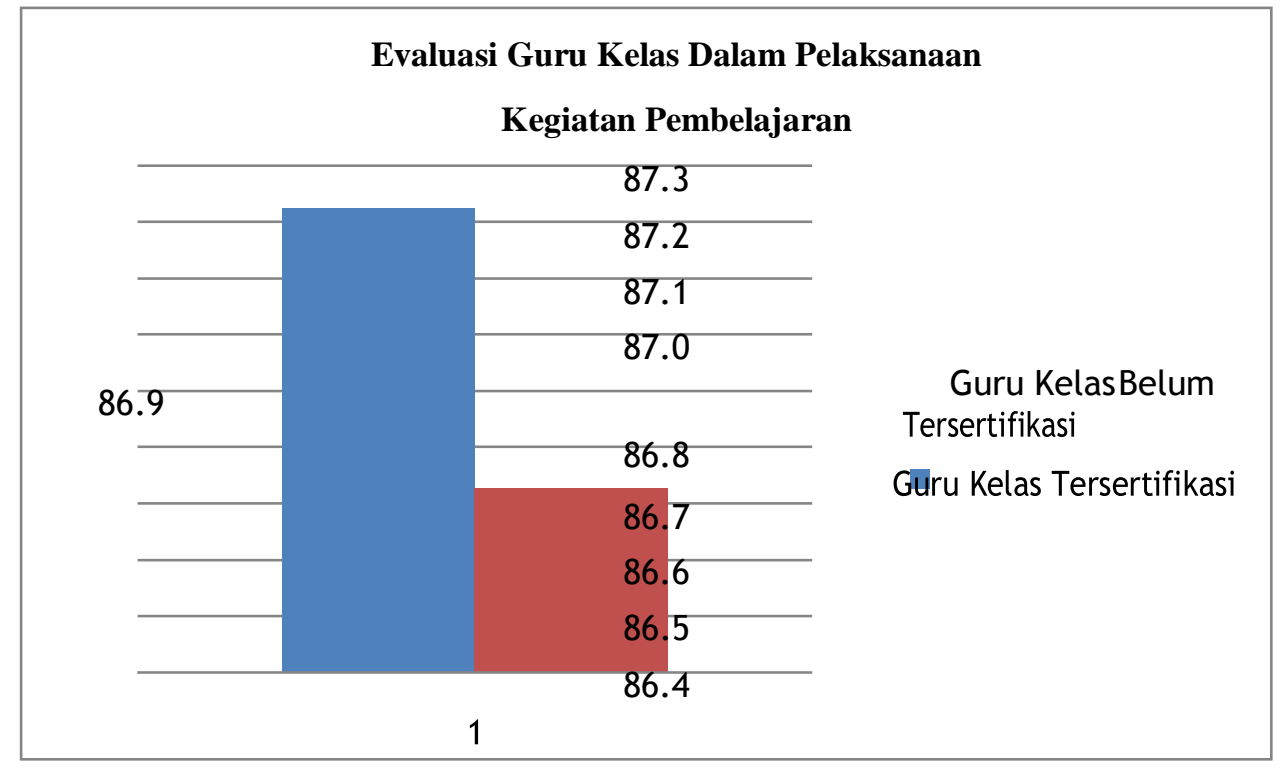

\section{Diagram 3. Evaluasi Guru Kelas dalam Pelaksanaan Kegiatan Pembelajaran}

Based on the above data, it is known that certified class teachers get an average score of 86.7, in carrying out their professional assignments in learning activities, meanwhile the uncertified class teachers get an average score of 87.2 in carrying out their professional assignments in learning activities at the level primary education in primary schools in Jakarta, Bogor, Depok, Tangerang and Bekasi. From the acquisition of the score, if it is converted into a value, it can be described qualitatively that certified and uncertified class teachers can carry out learning activities very well, so that for learning activities both certified and uncertified class teachers can continue to strive to maintain quality in carrying out activities the learning. Even though it appears that the certified class teacher has a superior score, but apparently this is influenced by the experience in carrying out learning for a long time, so that the awarding of certificates is actually just a form of recognition of the competencies owned by class teachers, does not mean that those who have not been certified yet have competence in implementing learning. 


\section{CONCLUSION}

Based on the results of the study it can be concluded that $80 \%$ of elementary school classroom teachers can professionally carry out their duties very well. however it is known that in planning learning activities certified class teachers have good quality assurance compared to uncertified class teachers. Meanwhile, in the implementation of learning activities, classroom teachers with certified as well as non-certified have very good quality. This means that the existence of a teacher certificate for class teachers is a form of professional recognition of ownership of competence as a classroom teacher in carrying out learning activities in elementary schools

\section{DAFTAR PUSTAKA}

Bambang S. Sulasmono (2015) Evaluasi Kinerja Mengajar Guru Kelas V Bersertifikasi Di Daerah Binaan 2 Kecamatan Parakan. Jurnal Manajemen Pendidikan: Vol. 2 N0 1 86-98 : https://ejournal.uksw.edu/kelola/issue/view/73

Bybee, W., Rodger 2009. The Bscs 5E Instructional Model And 21st Century Skills,

Colker, Laura J. 2008 Twelve Characteristics of Effective Early Childhood Teachers, Beyond the Journal, Young Childrenon theWeb

Crooks, Terence J., 1988 The Impact of Classroom Evaluation Practices on Students Review of Educational Research Winter, Vol.58, No.4,pp. 438- 481 University of Otago

Gao, Minghui, dan Liu, Qinghua, 2013 Personality Traits of Effective Teachers Represented in the Narratives of American and Chinese Preservice Teachers: A Cross-Cultural Comparison. International Journal of Humanities and Social Science Vol. 3 No. 2

Gulikers, Judith T. M. etc., 2004 A Five-Dimensional Framework for Authentic Assessment, ETR\&D, Vol. 52, No. 3, 2004, pp. 67-86 ISSN 1042-1629

http://journal.unnes.ac.id/index.php/LIK/article/download/520/477

John Wiley \& Sons Inc.

Permendikbud No 22 tahun 2016 tentang standar proses

Poulsen, Aura, dkk., 2008. ARCS Model of Motivational Design. EDTEC 544

Purnomo, Arif, 2007 Kemampuan Guru Dalam Merancang Tes Berbentuk Pilihan Ganda Pada Mata Pelajaran IPS Untuk Ujian Akhir Sekolah (UAS). Scientific Jorunal. Vol 3. 87-96 
Evaluating the Professional Duties of Classroom Teachers in Primary Schools

Smith, L., Patricia \& Tillman J., Ragan., tt. Instructional Design, Second Edition.

Sugiyono 2012. Metode Penelitian Pendidikan; pendekatan kuantitatif, kualitatif, dan Re D. Alfabeta: Bandung

The National Academies Board on Science Education

Yin, .K., Robert, 2011. Qualitative Research From Start To Finish. The gillford Press. New York, London 